Karin Corrêa Scheffer'

Maria Luiza Carrieri'

Avelino Albas"

Helaine Cristina Pires dos

Santos ${ }^{1}$

\section{Ivanete Kotait'}

Fumio Honma Ito"'I

Instituto Pasteur de São Paulo. São Paulo, SP, Brasil

" Pólo Regional de Desenvolvimento Tecnológico dos Agronegócios da Alta Sorocabana. Presidente Prudente, SP, Brasil

III Faculdade de Medicina Veterinária e Zootecnia. Universidade de São Paulo. São Paulo, SP, Brasil

\section{Correspondence:}

Karin Corrêa Scheffer

Instituto Pasteur - Seção de Diagnóstico

Av. Paulista, 393 Cerqueira Césa

01311-000 São Paulo, SP, Brasil

E-mail: ksferreira@pasteur.saude.sp.gov.br

\section{Rabies virus in naturally infected bats in the State of São Paulo, Southeastern Brazil}

\section{ABSTRACT}

OBJECTIVE: To identify the species of bats involved in maintaining the rabies cycle; to investigate the distribution of the rabies virus in the tissues and organs of bats and the time taken for mortality among inoculated mice.

METHODS: From April 2002 to November 2003, bats from municipalities in the State of São Paulo were screened for the presence of the rabies virus, by means of direct immunofluorescence. The virus distribution in the bats was evaluated by inoculating mice and N2A cells with $20 \%$ suspensions prepared from fragments of different organs and tissues, plus the brain and salivary glands. The time taken for mortality among the mice was monitored daily, following intracerebral inoculation.

RESULTS: Out of the 4,395 bats received, 1.9\% were found positive for the rabies virus. They belonged to ten genera, with predominance of insectivores. The maximum mean times taken for mortality among the mice following inoculation with brain and salivary gland material were $15.33 \pm 2.08$ days and $11.33 \pm 2.30$ days for vampire bats, $16.45 \pm 4.48$ days and $18.91 \pm 6.12$ days for insectivorous bats, and $12.60 \pm 2.13$ days and $15.67 \pm 4.82$ days for frugivorous bats, respectively.

CONCLUSIONS: The species infected with the rabies virus were: Artibeus lituratus, Artibeus sp., Myotis nigricans, Myotis sp., Eptesicus sp., Lasiurus ega, Lasiurus cinereus, Nyctinomops laticaudatus, Tadarida brasiliensis, Histiotus velatus, Molossus rufus, Eumops sp. and Desmodus rotundus. Virus investigation in the different tissues and organs showed that the brain and salivary glands were the most suitable sites for virus isolation.

KEYWORDS: Rabies vírus, isolation \& purification. Rabies, virology. Chiroptera, virology. Mice, virology. Cell culture techniques.

\section{INTRODUCTION}

Rabies is a disease maintained in the natural environment by different domestic and wild species of the orders Carnivora and Chiroptera that present a variety of feeding habits. These species are called reservoirs. ${ }^{20}$

The involvement of vampire bats in transmitting the rabies virus was suggested at the beginning of last century. ${ }^{4}$ The hypothesis was confirmed by Haupt \& Rehaag, ${ }^{11}$ who identified the presence of Negri bodies in the central nervous system of a vampire bat that was feeding on a cow. Vampire bats, and especially Desmodus rotundus, are the reservoirs for the rabies virus in Latin American countries, ${ }^{21}$ and are endemic in the region stretching from northern Chile and northern Argentina to northern Mexico and parts of the Caribbean. ${ }^{13}$ 
In 1953, in Florida (United States), a boy was attacked by the insectivorous bat Lasiurus intermedius, and this made American researchers turn their attention to the question of rabies in non-vampire bats. ${ }^{2}$ Shortly afterwards, rabies virus infection was confirmed in different bat species of distinct feeding habits, including insectivores, frugivores, omnivores, pollinivores and piscivores. ${ }^{1}$

Over recent years, reports of isolation of the rabies virus or viruses looking like the rabies virus, from bats with a variety of feeding habits, have become frequent around the world. Many of these viruses have been called "emerging" lyssaviruses.

The rabies virus belongs to the genus Lyssavirus of the family Rhabdoviridae, order Mononegavirales, and in the current classification the genus Lyssavirus contains seven genotypes. ${ }^{10}$ Of these, only genotype III (Mokola virus) has not been isolated from insectivorous bats.* A further four viral variants have now been suggested, to form new genotypes for Lyssavirus, all isolated from bats. ${ }^{3}$ Lyssavirus genotype I has only been recorded on the American continent and in the Caribbean. ${ }^{9}$

In Brazil, up to 2003, involvement of vampire bats in transmitting rabies to humans was infrequently described. ${ }^{17}$ However, in 2005, out of the 45 recorded cases of human rabies, 42 were transmitted by vampire bats. ${ }^{* *}$ On the other hand, there are few records of transmission of the rabies virus by non-vampire bats to terrestrial wild animals. This form of transmission, if confirmed, would require specific control measures. ${ }^{1}$

Since Silva \& Souza ${ }^{19}$ reviewed the topic of rabies virus research on vampire bats, new perspectives for better knowledge of the particular features of rabies in these animals have been opened up. Nilsson \& Nagata $^{16}$ isolated the rabies virus from the brain, salivary glands, interscapular fat, heart, lungs and testicles of a specimen of Desmodus rotundus.

Knowledge of matters relating to the pathogenesis and epidemiology of rabies in different bat species is important for controlling the disease in these animals, and also in herbivores, pets and humans.

The objectives of the present study were to identify the bat species involved in maintaining the rabies cycle in the State of São Paulo and to investigate the distribution of the rabies virus in bat tissues and organs and the time taken for mortality among inoculated mice.

\section{METHODS}

Between April 2002 and November 2003, the Diagnosis Sector of the Instituto Pasteur of São Paulo received 4,393 bats from 261 municipalities in the State of São Paulo for routine laboratory examination. The animals that were positive for the rabies virus were identified to genus and/or species level, in accordance with Vizotto \& Taddei. ${ }^{22}$ In addition to this, the feeding habits of these animals were recorded (Table 1).

Brain tissue samples from all the bats received were subjected to the direct immunofluorescence test, as described by Dean et al, ${ }^{6}$ in order to investigate the presence of the rabies antigen. The Challenge Virus Standard (CVS), sample CVS/31, was utilized, with adaptation to mouse brains. This presented a titer of $10^{6} \mathrm{DLIC}_{50} / 0.03$ $\mathrm{mL}$ for obtaining a virus suspension for absorption of the anti-rabies conjugate. The bats diagnosed positive
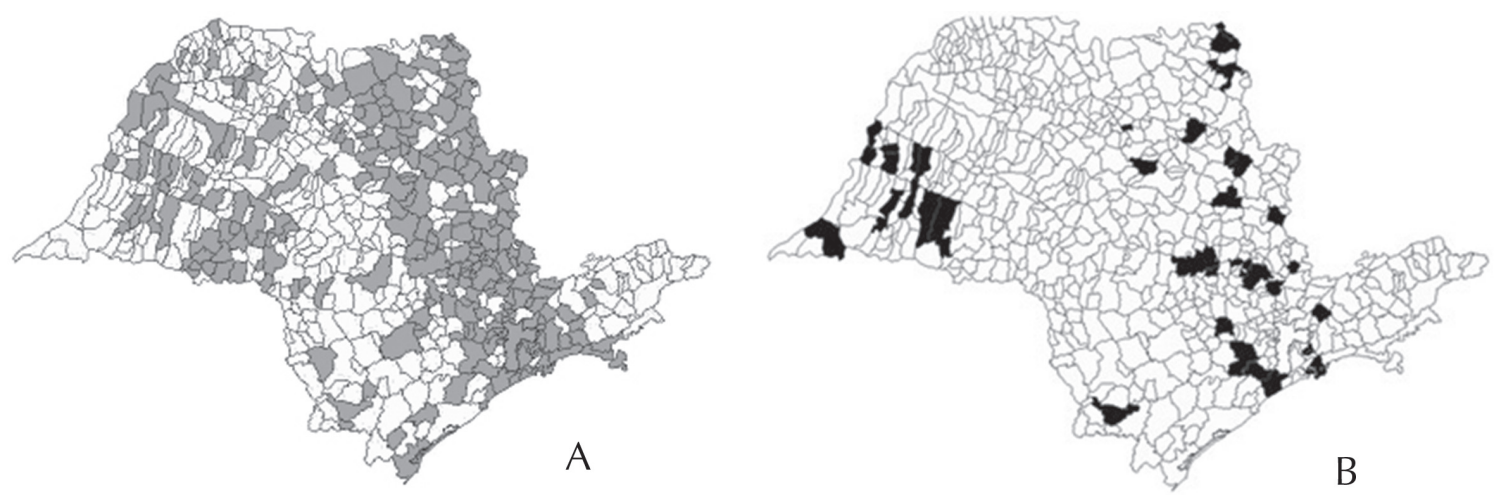

Figure. A) Municipalities of the State of São Paulo that sent bats for rabies diagnosis. B) Origins of bats that were diagnosed positive for rabies using the direct immunofluorescence test. State of São Paulo, Brazil, April 2002 to November 2003.

\footnotetext{
* Nel LH. Mokola virus: a brief review of the status quo. 6th Conference of the southern and eastern African rabies group. Lilongwe, Malawi, June 2001.

** Ministério da Saúde - Programa Nacional de Profilaxia da Raiva. Casos de raiva humana notificados, e percentual de casos transmitidos segundo a espécie animal. Brasília; 2005
} 
for rabies came from various municipalities, and these are highlighted in the Figure.

Fragments of brain tissue, salivary gland, pectoral muscle, heart, lungs, stomach, kidneys, urinary bladder, genital tract, tongue and interscapular fat were taken from the positive animals. These fragments were separately macerated in $0.85 \%$ physiological solution and then $2 \%$ bovine fetal serum (free of anti-rabies antibodies) and 1 $\mathrm{mL}$ of garamycin per liter of diluent were added. This suspension was kept under refrigeration for $30 \mathrm{~min}$ and centrifuged at $3000 \mathrm{rpm}$ for $30 \mathrm{~min}$. Not all the tissues and organs were in a condition to be subjected to the virus isolation test in mice and/or cell culture. Thus, for 40 specimens, suspensions of both brains and salivary glands were utilized.

The intracerebral inoculation in mice followed the technique described by Koprowski. ${ }^{14}$ The mice used were 21-day-old Swiss albinos weighing between 12 and $14 \mathrm{~g}$, which were obtained from the vivarium of the Instituto Pasteur of São Paulo. These were inoculated with $0.03 \mathrm{~mL}$ of inoculum. Groups of five to seven individuals per sample were utilized. After inoculation, the animals were observed for 30 days. The minimum time taken for mortality was defined as the number of days between inoculation and the date of the first death, and the maximum time taken for mortality as the number of days between inoculation and the date of the last death. To confirm the presence of the rabies virus in the animals that died during the observation period, their brains were subjected to the direct immunofluorescence technique.

For inoculation into cell cultures, murine neuroblastoma (N2A) cell culture coming from the American Type Culture Collection (ATCC; Virginia, USA) was used. $40 \mu \mathrm{L}$ of previously prepared inoculum was placed in a 96-well plate with $160 \mu \mathrm{L}$ of minimum essential medium (MEM), gentamycin and nonessential amino acids. After homogenization, $100 \mu \mathrm{L}$ of suspension of N2A cells (containing $5 \times 10^{5}$ cells) was added to each well. Each sample was tested in triplicate. To develop the test, the technique described by Webster \& Casey ${ }^{23}$ was used and the reading was done using an inverted fluorescence microscope.

The study was conducted within the required ethical standards and was approved by the bioethics committee of the Faculdade de Medicina Veterinária e Zootecnia of the Universidade de São Paulo.

\section{RESULTS}

Out of the total of 4,393 animals analyzed, 3,978 (90.5\%) were non-vampire bats and 415 (9.4\%) were vampire bats. The total rabies-positive rate was $1.9 \%$ $(82 / 4,393)$, and it was $1.4 \%(6 / 415)$ among the vampire bats and $1.9 \%(76 / 3,978)$ among the non-vampire bats. The bats that were positive for rabies belonged to the following genera: Artibeus, Myotis, Eptesicus, Lasiurus, Nyctinomops, Tadarida (T. brasiliensis), Histiotus, Molossus, Eumops and Desmodus (D. rotundus).

Regarding the feeding habits of the rabies-positive bats, 43 were insectivores, predominantly of species in the genera Myotis (15/82) and Eptesicus (10/82); 33 were frugivores, all from the genus Artibeus; and six were vampires (Desmodus rotundus) (Table 1).

The results from inoculating the fragments of tissues and organs from rabies-positive bats into mice and into N2A cell cultures are presented in Tables 2 and 3. It was observed that the number of false negative diagnoses was lower when using the mice (8) than when using the cell culture (11).

The minimum time taken for mortality caused by the virus isolated from the brain samples ranged from seven

Table 1. Identification of the genera and feeding habits of bats that tested positive for rabies using the direct immunofluorescence test. State of São Paulo, Brazil, April 2002 to November 2003.

\begin{tabular}{lccc}
\hline Bat genera & Feeding habits & Number of specimens $(\mathrm{N})$ & Tested positive $(\%)$ \\
\hline Artibeus & frugivore & 33 & 40.2 \\
Myotis & insectivore & 15 & 18.3 \\
Eptesicus & insectivore & 10 & 12.2 \\
Desmodus & vampire & 6 & 07.3 \\
Lasiurus & insectivore & 5 & 06.1 \\
Nyctinomops & insectivore & 4 & 04.9 \\
Tadarida & insectivore & 4 & 04.9 \\
Histiotus & insectivore & 3 & 03.7 \\
Molossus & insectivore & 1 & 01.2 \\
Eumops & insectivore & 1 & 01.2 \\
\hline Total & & 82 & 100.0 \\
\hline
\end{tabular}


Table 2. Distribution of the rabies virus in the tissues and organs of naturally infected bats, evaluated by means of intracerebral inoculation in mice. State of São Paulo, Brazil, April 2002 to November 2003.

\begin{tabular}{lccc}
\hline Tissues and organs & Positive $(\%)$ & Negative $(\%)$ & Inoculated \\
\hline Brain & $68(89.5)$ & $8(10.5)$ & 76 \\
Salivary gland & $44(57.9)$ & $32(42.1)$ & 76 \\
Tongue & $25(32.9)$ & $51(67.1)$ & 76 \\
Urinary bladder & $23(29.1)$ & $56(70.9)$ & 79 \\
Heart & $20(25.3)$ & $59(74.7)$ & 79 \\
Lungs & $18(22.8)$ & $61(77.2)$ & 79 \\
Interscapular fat & $16(24.2)$ & $50(75.8)$ & 66 \\
Kidneys & $9(11.2)$ & $71(88.8)$ & 80 \\
Genital tract & $3(05.5)$ & $52(94.5)$ & 55 \\
Stomach & $2(03.1)$ & $63(96.9)$ & 65 \\
Pectoral muscle & $1(01.3)$ & $74(98.7)$ & 75 \\
\hline
\end{tabular}

Table 3. Distribution of the rabies virus in the tissues and organs of naturally infected bats, evaluated by means of inoculation in N2A cell cultures. State of São Paulo, Brazil, 2002 to November 2003.

\begin{tabular}{lccc}
\hline Tissues and organs & Positive $(\%)$ & Negative $(\%)$ & Inoculated \\
\hline Brain & $56(83.6)$ & $11(16.4)$ & 67 \\
Salivary gland & $29(45.3)$ & $35(54.7)$ & 64 \\
Tongue & $10(17.5)$ & $47(82.5)$ & 57 \\
Urinary bladder & $7(11.1)$ & $56(88.9)$ & 63 \\
Heart & $6(15.0)$ & $34(85.0)$ & 40 \\
Lungs & $21(48.8)$ & $22(51.2)$ & 43 \\
Interscapular fat & $13(24.5)$ & $40(75.5)$ & 53 \\
Kidneys & $7(16.7)$ & $35(83.3)$ & 42 \\
Genital tract & $6(13.9)$ & $37(86.1)$ & 43 \\
Stomach & $4(11.1)$ & $32(88.9)$ & 36 \\
Pectoral muscle & $4(08.9)$ & $41(91.1)$ & 45 \\
\hline
\end{tabular}

to 20 days and the maximum time taken ranged from ten to 27 days. In turn, the salivary gland samples had a minimum time taken ranging from seven to 26 days, and a maximum time taken ranging from nine to 31 days, as shown in Table 4.

\section{DISCUSSION}

The proportion of $82(1.9 \%)$ specimens with positive reactions cannot be interpreted as the real prevalence of rabies in bats in the State of São Paulo, since this relates to positive findings from the direct immunofluorescence test.

According to Baer, ${ }^{1}$ in surveys carried out in the 1950 s and 1960s in the United States, the prevalence of rabies in non-vampire bats was variable but generally less than $1 \%$. Also according to studies from the 1950s carried out in the United States, one of the factors influencing the prevalence was whether the bats had solitary or gregarious habits. Among the rabies-positive bats identified in this study, $6 \%$ presented solitary habits; $73 \%$ formed small colonies (up to 20 specimens) and $21 \%$ formed large colonies.

In the present study, the bats of the genus Artibeus sent to the Instituto Pasteur for rabies diagnosis were confirmed as having synanthropic habits. Histories of contact and/or aggression towards people or domestic animals were reported, or else these bats were captured for the purposes of epidemiological surveillance, mostly in urban environments.

Insectivorous bats were the most frequent type among the positive cases, which may reflect the greater density of this group of bats in this State. ${ }^{17}$ The bats Artibeus lituratus and Desmodus rotundus presented rabies virus infection with a specific profile that was identified with a panel of monoclonal antibodies, and this variant of the virus is known as variant 3 , or Desmodus rotundus 
Table 4. Time taken for mortality among mice inoculated intracerebrally with suspensions of brains and salivary glands from bats, according to feeding habits. State of São Paulo, Brazil, April to November 2003.

\begin{tabular}{lccccc}
\hline Feeding habit & $\begin{array}{c}\text { Number of } \\
\text { bats }(\mathrm{N})\end{array}$ & $\begin{array}{c}\text { Minimum } \\
\overline{\mathrm{X}}_{ \pm \mathrm{SD}}\end{array}$ & $\begin{array}{c}\text { Maximum } \\
\overline{\mathrm{X}}_{ \pm \mathrm{SD}}\end{array}$ & $\begin{array}{c}\text { Minimum } \\
\overline{\mathrm{X}}_{ \pm \mathrm{SD}}\end{array}$ & $\begin{array}{c}\text { Maximum } \\
\overline{\mathrm{X}}_{ \pm} \mathrm{SD}\end{array}$ \\
\hline Vampire & 3 & $10.67 \pm 1.52$ & $15.33 \pm 2.08$ & $10.00 \pm 0.00$ & $11.33 \pm 2.30$ \\
Insectivore & 22 & $13.14 \pm 3.41$ & $16.45 \pm 4.48$ & $14.63 \pm 5.52$ & $18.91 \pm 6.12$ \\
Frugivore & 15 & $10.33 \pm 2.02$ & $12.60 \pm 2.13$ & $12.93 \pm 3.28$ & $15.67 \pm 4.82$ \\
\hline
\end{tabular}

$\overline{\mathrm{X}}_{ \pm \mathrm{SD}}=$ arithmetic mean \pm standard deviation (days)

variant. ${ }^{7}$ On the other hand, the phylogenetic analysis on the rabies virus isolated from Artibeus lituratus and Artibeus planirostris in the State of São Paulo revealed similarities with samples isolated from Desmodus rotundus. ${ }^{18}$

Studies on the rabies virus in the tissues or organs of naturally infected bats are rare. The rabies virus has been isolated by intracerebral inoculation into mice, from organs such as the heart, lungs, kidneys, bladder and interscapular gland of Desmodus rotundus, but in single cases. ${ }^{16,17}$

Studies on experimental infection in Desmodus rotundus and investigations on virus presence in these animals' organs and tissues have reported isolation of the virus from the salivary glands and lungs. ${ }^{15}$ In the insectivorous bat Eptesicus serotinus, the virus was investigated using swabs from the oropharynx and the RT-PCR test gave positive results. However, the virus was not identified or isolated from cerebral tissue. ${ }^{8}$

The Mokola virus (MOKV), genotype III of the genus Lyssavirus, has been described in the literature as a viscerotropic virus. * However, it may be gathered that viruses of genotype I or the classical rabies viruses isolated from bats in the State of São Paulo are also viscerotropic. For the purposes of isolating the rabies virus, the material most recommended is the brain, both in mice and in cell cultures. The salivary gland presents the second best result, in the mouse system. In N2A cell cultures, the third most common tissue with positive results was the lungs.

Recently, in a study conducted on two specimens of Myotis daubentonii, the genome of a virus looking like rabies (EBL2) was isolated and quantified in various organs, including the tongue, liver, bladder, kidneys, intestine and stomach. ${ }^{12}$

In many samples it was not possible to isolate the virus in cells because of bacterial contamination, especially when the materials were removed from animals that were found dead. In cases of positive isolation in cells, 96 hours of observation were enough, thus confirming the data of Webster \& Casey ${ }^{24}$ who established that four days was the ideal time period for isolating the rabies virus, especially from samples with low viral titers.

In the present study, the evidence showing rabies virus in the lungs reinforces the theory of rabies transmission between bats by means of aerosols, especially in caves that are densely populated with infected bats. ${ }^{5}$ The evidence showing rabies virus in the bladder, kidneys and stomach reinforces the importance of distribution of the virus among bats and suggests that there is a potential for rabies transmission by means of these animals' urine and feces. ${ }^{12}$ The presence of the virus in the tongue and salivary glands allows the conclusion that the most common transmission route among bats is by biting.

Regarding the time taken for mortality, the results from the present study corroborate the findings of Webster $\&$ Casey. ${ }^{24}$ The small differences observed in the present study in relation to the time taken for mortality may have resulted from differences in viral load in the brain and salivary glands, presence of neutralizing antibodies in the tissue suspensions used as inocula, or high ambient temperature in the vivarium, which may have influenced the start of clinical signs, diminished the mortality and increased the frequency of abortive infection in the inoculated animals. ${ }^{24}$

As shown in Table 4, the minimum time taken for mortality for the brain and salivary gland material from bats with different feeding habits was less than 21 days. The nine-day reduction in the daily observation of these animals may signify a saving in the expenditure on maintenance and on carrying out this test, in comparison with the conventional 30 days.

The use of a cell culture system for diagnosing rabies has been defended by many professionals and institutions that are concerned about the use of animals in experimentation and scientific research.

* Nel LH. Mokola virus: a brief review of the status quo. 6th Conference of the southern and eastern African rabies group. Lilongwe, Malawi, June 2001 
Screening by means of the direct immunofluorescence test in order to subsequently subject the material to intracerebral inoculation tests in mice and inoculation in cell cultures contributed towards obtaining positive results from both biological systems.

The dissemination of the rabies virus in different tissues and organs, and also in the central nervous system and salivary glands, contributed towards reinforcing the theories of other forms of rabies transmission in these animals. It also confirms the risk of infection among humans and domestic animals when they are in contact with dead or live bats of any species, or even with their urine or feces.

The results obtained from the present study emphasize the importance of maintaining post-exposure prophylactic treatment for humans (serum and vaccine) following contact with bats. There is a need for studies using different treatment schemes for pets according to their immunological status, in situations of contact with bats. 


\section{REFERENCES}

1. Baer GM. Rabies in nonhematophagous bats. In: Baer GM. The natural history of rabies. New York: Academic Press; 1975. p. 79-97.

2. Bigler WJ, Hoff GL, Buff EE. Chiropteran rabies in Florida: a twenty-year analysis, 1954 to 1973. Am J Trop Med Hyg. 1974;24(2):347-52.

3. Botvinkin AD, Poleschuk EM, Kuzmin IV, Borisova TI, Gazaryan SV, Yager P, et al. Novel lyssaviruses isolated from bats in Russia. Emerg Infect Dis. 2003; 9(12):1623-5.

4. Carini A. Sur une grande épizootie de rage. Ann Inst Pasteur. 1911;25:843-6.

5. Constantine DG. Rabies transmission by non bite route. Publ Health Rep.1962; 77:287-9.

6. Dean DJ, Abelseth MK, Atanasiu P. The fluorescent antibody test. In: Meslin FX, Kaplan MM, Koprowiski $\mathrm{H}$, editores. Laboratory techniques in rabies 4.ed. Geneva: World Health Organization; 1996. p.88-95.

7. Delpietro HA, Gury-Dhomen F, Larghi OP, Mena-Segura C, Abramo L. Monoclonal antibody characterization of rabies virus strains isolated in the River Plate Basin. Zentralb/ Veterinarmed B. 1997;44(8):477-83.

8. Eschevarria JE, Avellon A, Juste J, Vera M, Ibanez C. Screening of active lyssavirus infection in wild bat populations by viral RNA detection on oropharingeal swabs. J Clin Microb. 2001;39(10):3678-83.

9. Fooks AR. The challenge of new and emerging lyssaviruses. Expert Rev Vaccines. 2004;3(4):333-6.

10. Gould AR, Hyatt AD, Lunt R, Kattenbelt JA, Hengstberger S, BlackselL SD. Characterisation of a novel lyssavirus isolated from Pteropid bats in Australia. Virus Res. 1998;54(2):165-87.

11. Haupt H, Rehaag H. Raiva epizoótica nos rebanhos de Santa Catarina, sul do Brasil, transmitida por morcegos. Bol Soc Bras Med Vet.1925;2:17-47.

12. Johnson N, Wakeley PR, Brookes SM, Fooks AR. European bat lyssavirus type 2 RNA in Myotis daubentonii. Emerg Infect Dis. 2006;12(7):1142-4.

13. Koopman KF. Systematics and distribution. In: Greenhall AM, Schmidt U, editores. Natural history of vampire bats. Florida: CRC Press;1988. p.7-17.
14. Koprowski $H$. The mouse inoculation test. In: Meslin FX, Kaplan MM, Koprowski H. Laboratory techniques in rabies. 4.ed. Geneva: World Health Organization 1996; p.80-7.

15. Moreno AJ, Baer GM. Experimental rabies in the vampire bat. Am J Trop Med Hyg. 1980;29(2):254-9.

16. Nilsson MR, Nagata CA. Isolamento do vírus rábico do cérebro, glândulas salivares e interescapular, coração, pulmões e testículos de morcegos Desmodus rotundus (Geoffroy, 1910), no Estado de São Paulo. Arq Inst Biol (Sao Paulo). 1975; 42(23):183-8.

17. Rosa EST, Kotait I, Barbosa TFS, Carrieri ML, Brandão PE, Pinheiro AS, et al. Bat-transmitted human rabies outbreaks, Brazilian Amazon. Emerg Infect Dis. 2006;12(8):1197-202.

18. Shoji Y, Kobayashi Y, Sato G, Itou T, Miura Y, Mikami T, et al. Genetic characterization of rabies viruses isolated from frugivorous bat (Artibeus spp.) in Brazil. J Vet Med Sci. 2004;66(10):1271-3.

19. Silva RA, Souza AMA. Isolamento do vírus rábico de pulmão, coração, rins, bexiga e outros diferentes tecidos de morcegos hematófagos da espécie Desmodus rotundus. Pesq Agrop Bras. 1968;3:291-301.

20. Smith JS. New aspects of rabies with emphasis on epidemiology, diagnosis, and prevention of the disease in the United States. Clin Microb Rev. 1996; 9(2):16676 .

21. Torres S, Queiroz Lima E. A raiva e os morcegos hematófagos infectados naturalmente. Rev Depart Nac Prod Animal.1935;3(1-6):165-174.

22. Vizotto LD, Taddei VA. Chave para determinação de quirópteros brasileiros. Rev Fac Filos Cien Letr $S$ José $R$ Preto Bolm Cienc. 1973(1):1-72.

23. Webster WA, Casey GA. Virus isolation in neuroblastoma cell culture. In: Meslin FX, Kaplan MM, Koprowski $\mathrm{H}$, editores. Laboratory techniques in rabies, 4.ed. Geneva: World Health Organization;1996. p.96104.

24. Webster WA, Casey GA. Diagnosis of rabies infection. In: Campbell JB, Charlton KM, editores. Rabies. Boston: Kluwer Academic Publishers; 1988. p.201-22.

Article based on master's dissertation by KC Scheffer, presented to Faculdade de Medicina Veterinária e Zootecnia of the Universidade de São Paulo, in 2005.

Supported by the Fundação de Amparo à Pesquisa do Estado de São Paulo (FAPESP - Research Support Foundation of the State of São Paulo grant no. 02/05855-0) and by the Instituto Pasteur, State Health Department of São Paulo. 